\title{
Antimicrobial Activity of Pyrrocidines from Acremonium zeae Against Endophytes and Pathogens of Maize
}

\author{
Donald T. Wicklow and Stephen M. Poling
}

\begin{abstract}
Mycotoxin Research Unit, National Center for Agricultural Utilization Research, U.S. Department of Agriculture-Agricultural Research Service, Peoria, IL 61604.

Accepted for publication 15 September 2008.
\end{abstract}

\section{ABSTRACT}

Wicklow, D. T., and Poling, S. M. 2009. Antimicrobial activity of pyrrocidines from Acremonium zeae against endophytes and pathogens of maize. Phytopathology 99:109-115.

Acremonium zeae produces pyrrocidines $\mathrm{A}$ and $\mathrm{B}$, which are polyketide-amino acid-derived antibiotics, and is recognized as a seedborne protective endophyte of maize which augments host defenses against microbial pathogens causing seedling blights and stalk rots. Pyrrocidine A displayed significant in vitro activity against Aspergillus flavus and Fusarium verticillioides in assays performed using conidia as inoculum, with pyrrocidine A being more active than B. In equivalent assays performed with conidia or hyphal cells as inoculum, pyrrocidine A revealed potent activity against major stalk and ear rot pathogens of maize, including $F$. graminearum, Nigrospora oryzae, Stenocarpella (Diplodia) maydis, and Rhizoctonia zeae. Pyrrocidine A displayed significant activity against seed-rotting saprophytes A. flavus and Eupenicillium ochrosalmoneum, as well as seed-infecting colonists of the phylloplane Alternaria alternata, Cladosporium cladosporioides, and Curvularia lunata, which produces a damaging leaf spot disease. Protective endophytes, including mycoparasites which grow asymptomatically within healthy maize tissues, show little sensitivity to pyrrocidines. Pyrrocidine A also exhibited potent activity against Clavibacter michiganense subsp. nebraskense, causal agent of Goss's bacterial wilt of maize, and Bacillus mojaviense and Pseudomonas fluorescens, maize endophytes applied as biocontrol agents, but were ineffective against the wilt-producing bacterium Pantoea stewartii.
The fungal endophyte Acremonium zeae W. Gams \& D. R. Sumner is antagonistic to kernel-rotting and mycotoxin-producing fungi Aspergillus flavus and Fusarium verticillioides in cultural tests for antagonism and interferes with A. flavus infection and aflatoxin contamination of preharvest maize (Zea mays) seed (56, 57,59). Chemical studies of an organic extract from maize kernel fermentations of Acremonium zeae NRRL 13540, which displayed significant antifungal activity against Aspergillus flavus and $F$. verticillioides, revealed that the metabolites accounting for this activity were two newly reported antibiotics, pyrrocidines A and B (Fig. 1) (59). The pyrrocidines were previously reported from the fermentation broth of an unidentified species of Cylindrocarpon, isolated from a mixed Douglas fir forest on Crane Island Preserve, WA, in 1993 (6,18). Pyrrocidines were detected in fermentation extracts for 12 NRRL cultures of Acremonium zeae isolated from maize seed harvested in the United States. Furthermore, pyrrocidine B was detected by liquid chromatographytandem mass spectrometry in whole symptomatic maize seed removed at harvest from ears of a commercial hybrid that were wound inoculated in the milk stage with $A$. zeae. This was the first report of natural products from A. zeae (59).

Dihydroresorcylide, a previously unknown macrocyclic lactone isolated from A. zeae and not related to the pyrrocidines (Fig. 1), was shown to be phytotoxic to maize using a leaf-puncture wound assay; however, no fungistatic activity was detected (35). Our objective was to compare the in vitro inhibitory activity of pyrrocidines A and B against common fungal endophytes and pathogens of maize which have been functionally classified as belong-

Corresponding author: D. T. Wicklow; E-mail address: donald.wicklow@ars.usda.gov

doi:10.1094/PHYTO-99-1-0109

This article is in the public domain and not copyrightable. It may be freely reprinted with customary crediting of the source. The American Phytopathological Society, 2009 ing to different ecological groups (54), including molds capable of infecting and rotting maize kernels while contaminating the grain with mycotoxins harmful to livestock as well as humans. Because pyrrocidine A exhibits potent activity against medically important gram-positive bacteria (18), we also wanted to evaluate the activity of pyrrocidines against selected bacterial pathogens and endophytes of maize, the latter having been identified for their biocontrol potential.

\section{MATERIALS AND METHODS}

Fungal inoculum and culture conditions. The cultures of fungi and bacteria used in this study (Tables 1 to 3) were obtained from the Agricultural Research Service Culture Collection, Peoria, IL. All of the cultures were isolated from maize with the exception of Verticillium lecanii NRRL 26576, isolated by D. T. Wicklow from the mushroom Amanita bisporigera (43), and reported to be a seedborne endophyte of maize (12). In our initial evaluation of Aspergillus flavus (NRRL 6541) and F. verticillioides (NRRL 25457) sensitivity to pyrrocidines A and B with traditional paper disc assays, plates were seeded with a suspension of filtered conidia (59). An equivalent filtered conidial inoculum was produced from the same fungal strains to evaluate the in vitro fungistatic activity of pyrrocidines A and B in experiments described below. A. flavus and $F$. verticillioides were grown in Roux bottles containing potato dextrose agar (PDA) for 14 days at $25^{\circ} \mathrm{C}$. Hyphal fragments and conidium-bearing structures (e.g., phialides and conidiophores) suspended in sterile distilled water were removed by filtering through a double layer of sterile cheese cloth. Potato dextrose broth (PDB) was seeded with $A$. flavus or $F$. verticillioides conidia, giving a final conidial suspension of $\approx 4 \times 10^{4} \mathrm{ml}^{-1}$ of PDB. Twenty fungal species representing different ecological groups isolated from corn (Table 2) were grown as PDA slant cultures for 6 days at $25^{\circ} \mathrm{C}$. A suspension of conidia or hyphal cells was prepared from these 
cultures and used as inoculum to seed PDB, giving a final propagule density of $\approx 4 \times 10^{4} \mathrm{ml}^{-1}$. Seed inoculum for bacterial cultures (Table 3) was produced in $100 \mathrm{ml}$ of tryptone glucose yeast extract (TGY) broth ( $5 \mathrm{~g}$ of tryptone, $5 \mathrm{~g}$ of yeast extract, $1 \mathrm{~g}$ of dextrose, $1 \mathrm{~g}$ of $\mathrm{K}_{2} \mathrm{HPO}_{4}$, and 1 liter of water) in a $500-\mathrm{ml}$ Erlenmeyer flask shaken at $130 \mathrm{rpm}$ for 18 to $36 \mathrm{~h}$ at $25^{\circ} \mathrm{C}$.

Isolation and purification of pyrrocidines $A$ and $\mathbf{B}$. The ethyl acetate extract from six freeze-dried 15-day-old cultures of Acremonium zeae NRRL 13540 grown on $200 \mathrm{~g}$ of corn at $25^{\circ} \mathrm{C}$ with a total weight of $55 \mathrm{~g}$ was separated by flash chromatography on silica. Two extracts were combined and each pair separated as follows. The extract was dissolved in $200 \mathrm{ml}$ of hexane and centrifuged at 1,700 rpm for $5 \mathrm{~min}$, and the hexane was decanted. A 10-g silica Sep-Pak cartridge (Waters Corp., Milford, MA) conditioned with $100 \mathrm{ml}$ of hexane and the extract in hexane was loaded onto the column. The column was eluted with $100 \mathrm{ml}$ of hexane, $100 \mathrm{ml}$ of ethyl acetate/hexane at $20 / 80,4 \times 50 \mathrm{ml}$ at $30 / 70,2 \times 50 \mathrm{ml}$ at $40 / 60,2 \times 50 \mathrm{ml}$ at $50 / 50,100 \mathrm{ml}$ at $70 / 30$, $100 \mathrm{ml}$ of ethyl acetate, and $100 \mathrm{ml}$ of methanol. Each fraction was analyzed by liquid chromatography-mass spectrometry (LC-

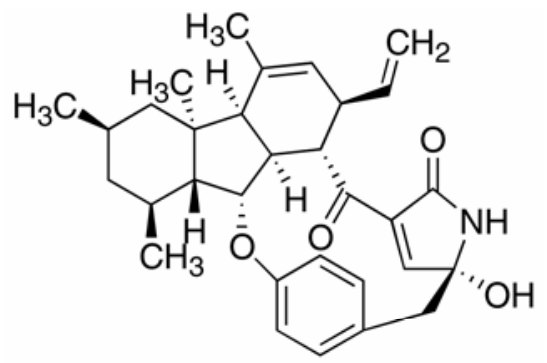

Pyrrocidine A

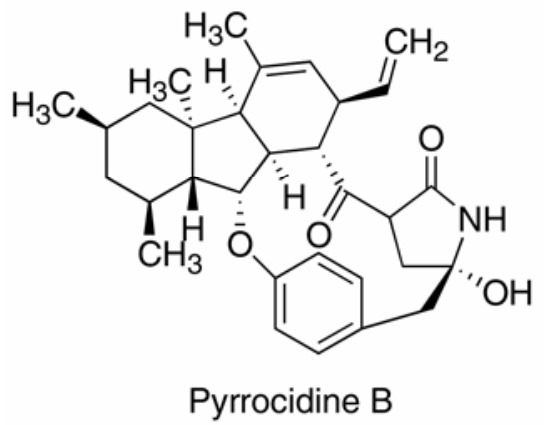<smiles>C[C@H]1CCCCCC(=O)Cc2cc(O)cc(O)c2C(=O)O1</smiles>

\section{Dihydroresorcylide}

Fig. 1. Chemical structures of pyrrocidine A, pyrrocidine B, and dihydroresorcylide, metabolites produced by Acremonium zeae.
MS). Pyrrocidine A was eluted with ethyl acetate/hexane at 30/70 and pyrrocidine B with ethyl acetate/hexane at 40/60 and 50/50. Each fraction was dried down with a rotary evaporator, transferred to vials with ethyl acetate, evaporated to dryness under a stream of filtered air, and stored in a freezer. The three pyrrocidine A fractions had a total weight of $589 \mathrm{mg}$ and the pyrrocidine $\mathrm{B}$ fractions weighed $611 \mathrm{mg}$. Each of the six fractions was further purified using a 10-g tC18 Sep-Pak cartridge (Waters Corp.). The cartridge was conditioned with $100 \mathrm{ml}$ of methanol followed by $100 \mathrm{ml}$ of acetonitrile/water (50/50). Pyrrocidine A fractions were dissolved in $2 \mathrm{ml}$ of ethyl acetate plus $48 \mathrm{ml}$ of acetonitrile. Pyrrocidine B fractions were dissolved in $50 \mathrm{ml}$ of acetonitrile. Before loading onto the conditioned cartridge, each fraction was diluted with $50 \mathrm{ml}$ of water. The cartridge was eluted with $100 \mathrm{ml}$ of 50/50 acetonitrile/water, $2 \times 50 \mathrm{ml}$ at $60 / 40,2 \times$ $50 \mathrm{ml}$ at $70 / 30,2 \times 50 \mathrm{ml}$ at $80 / 20,100 \mathrm{ml}$ of acetonitrile, and 100 $\mathrm{ml}$ of ethyl acetate. Each fraction was analyzed by LC-MS. Pyrrocidine A was eluted in both of the $2 \times 40 / 60$ fractions and the first only of the $2 \times 50 / 50$ fractions. Pyrrocidine B was eluted from both of the $2 \times 40 / 60$ fractions and the 70/30 fraction. The total weights of the three pyrrocidine A and B fractions were 263 and $402 \mathrm{mg}$, respectively. The pyrrocidine A fractions were stored in a freezer for 6 months before they were combined using ethyl acetate. LC-MS analysis showed that, during this time, some of the pyrrocidine A had oxidized to a product that was later identified as 17,18-epoxy-pyrrocidine A (11) and tentatively named pyrrocidine $\mathrm{C}$. The dried pyrrocidine A fraction was triturated with acetonitrile and the acetonitrile supernatant solution was set aside for the purification of pyrrocidine $\mathrm{C}$. The remainder was then crystallized from acetonitrile to give $76 \mathrm{mg}$ of pyrrocidine A as white lustrous flakes.

Later separations were performed using a Versaflash system (Supelco, Bellefonte, PA). The ethyl acetate extract from eight freeze-dried 15-day-old cultures of A. zeae NRRL 13540 grown on $200 \mathrm{~g}$ of rice at $25^{\circ} \mathrm{C}$ with a total weight of $20 \mathrm{~g}$ was separated using a VersaPak 40-by-75-mm silica cartridge (Supelco). The extract was dissolved in $400 \mathrm{ml}$ of hexane, centrifuged at 1,700 rpm, and the hexane decanted. The cartridge was conditioned with $400 \mathrm{ml}$ of hexane and the sample loaded. The column was eluted as above but using 200- and 400-ml increments instead of 50- and $100-\mathrm{ml}$ increments. The pyrrocidine A and B fractions weighed 298 and $376 \mathrm{mg}$, respectively. The methanol eluate was saved for the purification of the cerebrosides. The pyrrocidine A fraction was triturated twice with acetonitrile and once with hexane, which reduced the weight to $189 \mathrm{mg}$. Crystallization from acetonitrile gave $99 \mathrm{mg}$ of slightly yellow pyrrocidine A.

Extracts from 20 rice cultures were separated using a VersaPak silica cartridge as described above to give a pyrrocidine $\mathrm{B}$ fraction weighing $993 \mathrm{mg}$. Further separation on a VersaPak 40-by-75-mm C18 cartridge using 150- and 300-ml steps instead of 50- and 100-ml steps, as described above for the tC18 cartridge, reduced the weight of the pyrrocidine $\mathrm{B}$ fraction to $541 \mathrm{mg}$. This was combined with a 660-mg pyrrocidine B fraction obtained in the same way. The sample was dissolved in ethyl acetate and treated with activated charcoal (Darco G-60; EM Science, Gibbstown, $\mathrm{NJ})$. The filtered solution was dried under a filtered air stream and dissolved in boiling chloroform/hexane (1/25). The solution was allowed to cool and stand uncovered in a fume hood until most

TABLE 1. Antimicrobial activity of pyrrocidines A and B produced by Acremonium zeae to Aspergillus flavus and Fusarium verticillioides ${ }^{\mathrm{a}}$

\begin{tabular}{|c|c|c|c|c|c|c|}
\hline \multirow[b]{2}{*}{ Isolate } & \multicolumn{2}{|c|}{ Pyrrocidine A } & \multicolumn{2}{|c|}{ Pyrrocidine B } & \multicolumn{2}{|c|}{ Nystatin } \\
\hline & MIC & $\mathrm{GI}_{50}$ & MIC & $\mathrm{GI}_{50}$ & MIC & $\mathrm{GI}_{50}$ \\
\hline Aspergillus flavus NRRL 6541 & $\leq 5$ & $>1-50$ & $>50$ & $>50$ & $\leq 10$ & $>3-50$ \\
\hline Fusarium verticillioides NRRL 25457 & $\leq 10$ & $>2-50$ & $>50$ & $>25-50$ & $\leq 25$ & $>5-50$ \\
\hline
\end{tabular}

${ }^{a}$ Inoculum was a conidial suspension filtered through sterile cheese cloth. Concentrations tested were 1, 2, 3, 5, 10, 25, and 50 $\mu \mathrm{g} / \mathrm{ml}$. MIC = minimum inhibitory concentration and $\mathrm{GI}_{50}=$ growth inhibition $>50 \%$ relative to the control. 
but not all of the solvent had evaporated. Pyrrocidine B precipitated as a fine powder. This was resuspended in hexane and, after filtering, gave $237 \mathrm{mg}$ of pyrrocidine B.

Comparison of in vitro activities. A minimal inhibitory concentration (MIC) was assigned to the smallest treatment concentrations for which no fungal or bacterial growth was recorded and another value was designated when fungal or bacterial growth inhibition exceeded $50 \%$ of the growth recorded for methanol control wells $\left(\mathrm{GI}_{50}\right)$. Pyrrocidines $\mathrm{A}$ and $\mathrm{B}$ were evaluated in 96well plates with a growth area of $0.32 \mathrm{~cm}^{2}$ and volume of $370 \mu \mathrm{l}$
(BD Primaria Clear 96-well Microtest Plate No. 353872; Becton Dickinson, Franklin Lakes, NJ.) at concentrations of 1, 2, 3, 5, 10, 25 , and $50 \mu \mathrm{g} / \mathrm{ml}$.

The inhibitory activity of the broad-spectrum antifungal agent nystatin (Sigma-Aldrich, St. Louis) was also evaluated for potential inhibitory activity (MIC and $\mathrm{GI}_{50}$ ) against this collection of fungal endophytes and pathogens of maize, serving as a positive control. Appropriate dilutions of the test compound in $10 \mu \mathrm{l}$ of methanol were added to each of eight replicate wells and evaporated to dryness. Eight replicate wells received $10 \mu \mathrm{l}$ of methanol

TABLE 2. Antimicrobial activity of pyrrocidines A and B to fungal endophytes and pathogens of maize ${ }^{\mathrm{a}}$

\begin{tabular}{|c|c|c|c|c|c|c|}
\hline \multirow[b]{2}{*}{ Pathogens and endophytes } & \multicolumn{2}{|c|}{ Pyrrocidine A } & \multicolumn{2}{|c|}{ Pyrrocidine B } & \multicolumn{2}{|c|}{ Nystatin } \\
\hline & MIC & $\mathrm{GI}_{50}$ & MIC & $\mathrm{GI}_{50}$ & MIC & $\mathrm{GI}_{50}$ \\
\hline \multicolumn{7}{|c|}{ Stalk- and ear-rotting pathogens } \\
\hline \multicolumn{7}{|c|}{ Fusarium graminearum } \\
\hline NRRL 31250 & $\leq 1$ & $<1-50$ & $>50$ & $>50$ & $\leq 5$ & $>1-50$ \\
\hline \multicolumn{7}{|l|}{ Nigrospora oryzae } \\
\hline NRRL 6414 & $\leq 1$ & $<1-50$ & $\leq 10$ & $>5-50$ & $\leq 5$ & $\approx 2-50$ \\
\hline NRRL 40186 & $\leq 2$ & $<1-50$ & $>50$ & $>10-50$ & $\leq 10$ & $>3-50$ \\
\hline NRRL 40187 & $\leq 2$ & $<1-50$ & nt & nt & nt & nt \\
\hline \multicolumn{7}{|c|}{ Stenocarpella (Diplodia) maydis } \\
\hline NRRL 13615 & $\leq 1$ & $<1-50$ & $\leq 25$ & $>10-50$ & $\leq 1$ & $<1-50$ \\
\hline NRRL 31249 & $\leq 2$ & $<1-50$ & $\leq 25$ & $>5-50$ & $\leq 1$ & $<1-50$ \\
\hline \multicolumn{7}{|l|}{ Trichoderma viride } \\
\hline NRRL 6418 & $>50$ & $\approx 10-50$ & $>50$ & $>50$ & $>50$ & $>10-50$ \\
\hline NRRL 37597 & $>50$ & $\approx 25-50$ & $>50$ & $>50$ & $\leq 10$ & $>1-50$ \\
\hline \multicolumn{7}{|l|}{ F. proliferatum } \\
\hline NRRL 6413 & $>50$ & $\approx 25-50$ & $>50$ & $>25-50$ & $\leq 25$ & $>3-50$ \\
\hline NRRL 13569 & $>50$ & $>10-50$ & $>50$ & $>50$ & $\leq 10$ & $\approx 2-50$ \\
\hline NRRL 22058 & $>50$ & $>50$ & $>50$ & $>50$ & $\leq 10$ & $>2-50$ \\
\hline \multicolumn{7}{|l|}{ F. subglutinans } \\
\hline NRRL 22002 & $>50$ & $>10-50$ & $>50$ & $>50$ & $\leq 3$ & $>1-50$ \\
\hline NRRL 22034 & $>50$ & $\leq 50$ & $>50$ & $>50$ & $\leq 5$ & $>1-50$ \\
\hline F. verticillioides & & & & & & \\
\hline NRRL 25457 & $>50$ & $\approx 25-50$ & $>50$ & $>25-50$ & $\leq 10$ & $>3-50$ \\
\hline NRRL 13586 & $>50$ & $>10-50$ & $>50$ & $>25-50$ & $\leq 10$ & $>2-50$ \\
\hline NRRL 20984 & $>50$ & $>50$ & $>50$ & $>50$ & $\leq 10$ & $>3-50$ \\
\hline Mycoparasites -Fungicolot & & & & & & \\
\hline Penicillium funiculosum & & & & & & \\
\hline Aspergillus flavus & & & & & & \\
\hline NRRL 6541 & $>50$ & $>1-50$ & $>50$ & $\leq 50$ & $\leq 10$ & $>3-50$ \\
\hline A. niger & & & & & & \\
\hline NRRL 6411 & $>50$ & $>25-50$ & $>50$ & $>50$ & $\leq 50$ & $>2-50$ \\
\hline Eupenicillium ochrosalmo & & & & & & \\
\hline NRRL 6568 & $>50$ & $>1-50$ & $>50$ & $>50$ & $\leq 50$ & $>25-50$ \\
\hline P. oxalicum & & & & & & \\
\hline NRRL 6416 & $>50$ & $>25-50$ & $>50$ & $>50$ & $\leq 5$ & $>1-50$ \\
\hline Phylloplane - Foliar diseas & & & & & & \\
\hline Alternaria alternata & & & & & & \\
\hline NRRL 6410 & $\leq 10$ & $>1-50$ & $>50$ & $>10-50$ & $\leq 5$ & $>1-50$ \\
\hline Cladosporium cladosporic & & & & & & \\
\hline NRRL 6421 & $\leq 5$ & $>3-50$ & $>50$ & $\approx 50$ & $\leq 10$ & $>1-50$ \\
\hline Curvularia lunata & & & & & & \\
\hline NRRL 6409 & $>50$ & $>1-50$ & $>50$ & $>50$ & $\leq 5$ & $>2-50$ \\
\hline
\end{tabular}

${ }^{a}$ Inoculum was a suspension of conidia or hyphal cells from potato dextrose agar slant cultures grown for 6 days at $25^{\circ} \mathrm{C}$. Concentrations tested were $1,2,3,5,10$, 25 and $50 \mu \mathrm{g} / \mathrm{ml}$. MIC $=$ minimum inhibitory concentration, $\mathrm{GI}_{50}=$ growth inhibition $>50 \%$ relative to the control, and $\mathrm{nt}=$ not tested. 
and served as controls. PDB $(200 \mu \mathrm{l})$ seeded with each tested fungus or $200 \mu \mathrm{l}$ of TGY broth seeded with each bacterium $(1 \times$ $10^{8}$ cells $\mathrm{ml}^{-1}$ ) were added to experimental wells. Immediately before pipetting media seeded with microbes into experimental wells, $10 \mu \mathrm{l}$ of methanol was added to redissolve the test compound. The 96-well plates containing the fungi were incubated on a shelf for up to $64 \mathrm{~h}$ at $25^{\circ} \mathrm{C}$ and examined at 8- to 16-h intervals using a plate reader at a wave length of $550 \mathrm{~nm}$ (Dynatech MR 5000 with BioLinx Version 2.0 Assay Management Software; Dynatech Laboratories, Inc., Chantilly, VA) for evidence of inhibition of fungal growth in the wells, which is a measure of fungistatic activity. Plates containing bacteria were incubated on a shaker at $130 \mathrm{rpm}$ for up to $48 \mathrm{~h}$ at $25^{\circ} \mathrm{C}$ and examined at 8 - to 16-h intervals.

\section{RESULTS}

The results that follow contrast the sensitivities of common microbial endophytes and pathogens of maize to pyrrocidine antibiotics. In experiments using a filtered conidial inoculum, pyrrocidine A displayed significant in vitro activity against Aspergillus flavus ( $\mathrm{MIC}=\leq 5 \mu \mathrm{g} / \mathrm{ml}$ ) and $F$. verticillioides $(\mathrm{MIC}=\leq 10 \mu \mathrm{g} / \mathrm{ml}$ ), with pyrrocidine A being more active than B (Table 1). All other comparisons of the in vitro antifungal activities of pyrrocidines and nystatin (MIC) were performed using an inoculum consisting of the conidia or hyphal cells produced by individual test fungi in PDA slant cultures (Table 2). The MIC values of pyrrocidine A revealed potent activity of 1 to $2 \mu \mathrm{g} / \mathrm{ml}$ against major stalk and ear rot pathogens of maize that are also associated with pre- or postemergence seedling blights, including F. graminearum (holomorph: Gibberella zeae), Nigrospora oryzae (holomorph: Khuskia oryzae), Rhizoctonia zeae (holomorph: Waitea circinata), and Stenocarpella maydis $($ syn. = Diplodia maydis), while inhibiting the growth of Trichoderma viride (holomorph: Hypocrea sp.) $\left(\mathrm{GI}_{50} \approx 10\right.$ to $\left.50 \mu \mathrm{g} / \mathrm{ml}\right)$. Among all fungi tested, $N$. oryzae was the most sensitive to pyrrocidine B (MICs $=5$ to $10 \mu \mathrm{g} / \mathrm{ml}$ ). Pyrrocidine A also exhibited significant activity against dematiaceous hyphomycetes that colonize the phylloplane Alternaria alternata, Cladosporium cladosporioides (holomorph: Mycosphaerella tassiana) (MICs $=5$ to $10 \mu \mathrm{g} / \mathrm{ml})$ and the maize leaf spot pathogen Curvularia lunata (holomorph: Cochliobolus lunatus) $\left(\mathrm{GI}_{50}=\right.$ $>1$ to $50 \mu \mathrm{g} / \mathrm{ml}$ ). Kernel-rotting saprotrophs presented a wide range of sensitivity to pyrrocidine A, with Aspergillus flavus and Eupenicillium ochrosalmoneum $\left(\mathrm{GI}_{50} \mathrm{~s}=>1\right.$ to $\left.50 \mu \mathrm{g} / \mathrm{ml}\right)$ displaying greater sensitivity than A. niger and Penicillium oxalicum $\left(\mathrm{GI}_{50} \mathrm{~s}=>25\right.$ to $\left.50 \mu \mathrm{g} / \mathrm{ml}\right)$.

Symptomless 'protective' endophytes, including Acremonium zeae, F. oxysporum, F. proliferatum (holomorph: G. fujikuroi var. intermedia), F. subglutinans (holomorph: G. subglutinans), and
F. verticillioides (holomorph: G. moniliformis) displayed little or no sensitivity to pyrrocidines $\left(\mathrm{GI}_{50} \mathrm{~s}=>10\right.$ to $\left.50 \mu \mathrm{g} / \mathrm{ml}\right)$ yet were sensitive to nystatin (Table 2). At the same time, all of the fungi that were sensitive to pyrrocidine were also sensitive to nystatin. Pyrrocidine A was less active against $F$. verticillioides NRRL $25457\left(\mathrm{GI}_{50} \approx 25 \mu \mathrm{g} / \mathrm{ml}\right)$ than in tests in which filtered conidia composed the inoculum (Table 1). Mycoparasites, recorded as symptomless endophytes of maize seed or stalks, including $P$. funiculosum, P. pinophilum, P. variabile, and V. lecanii, revealed little sensitivity to pyrrocidines or nystatin (Table 2 ).

Pyrrocidine A also exhibited potent activity against Clavibacter michiganense subsp. nebraskense, causal agent of Goss's bacterial wilt of maize (MICs $=1$ to $2 \mu \mathrm{g} / \mathrm{ml}$ ), as well as Bacillus mojavensis (MICs $=1$ to $2 \mu \mathrm{g} / \mathrm{ml}$ ) and Pseudomonas fluorescens (MICs $=1$ to $2 \mu \mathrm{g} / \mathrm{ml}$ ), maize endophytes applied as biocontrol agents (Table 3$)$. The pyrrocidines were ineffective $(\mathrm{MICs}=$ $>50 \mu \mathrm{g} / \mathrm{ml}$ ) against the wilt-producing bacterium Pantoea stewartii subsp. stewartii (syn. Erwinia stewartii), and P. agglomerans (syn. Enterobacter agglomerans; Erwinia herbicola), an asymptomatic endophyte of maize.

\section{DISCUSSION}

Healthy maize plants become internally colonized with a diverse assemblage of microorganisms, a large majority of which are established as symptomless endophytic infections. Relatively few of these microbes are able to directly attack healthy maize tissues. A larger number produce disease symptoms in association with different forms of abiotic or biotic stress-related damage to plant tissues, which may cause premature senescence (52). Although some of these organisms are commonly recorded as pathogens of maize wherever it is grown and may also infect other cereals and grasses (Gramineae), others are isolated as pathogens of crops, belonging to different plant families, or are recognized as entomopathogens, mycoparasites, inhabitants of the rhizosphere, or common soil-inhabiting saprotrophs $(12,54,61)$. Maize grown in different climate zones and included in crop rotations developed for soil types within larger natural ecosystems can be expected to host locally adapted assemblages of microorganisms $(12,24,34,41)$. A. zeae is reported to be a prevalent fungal endophyte among such microbial assemblages of maize and has been shown to interfere with the in vitro growth of fungal pathogens of maize and produce pyrrocidine antibiotics $(56,59)$.

Pyrrocidines A and B displayed significant antifungal activity against $A$. flavus NRRL 6541 and $F$. verticillioides NRRL 25457 using conventional paper-disc assays in which PDA was seeded with a filtered conidial inoculum (59). In the present study, the in vitro activities (MIC) of pyrrocidines A and B were initially determined using a filtered conidial inoculum produced by the same

TABLE 3. Antimicrobial activity of pyrrocidines A and B to bacterial endophytes and pathogens of maize

\begin{tabular}{|c|c|c|c|c|}
\hline \multirow[b]{2}{*}{ Pathogens and endophytes } & \multicolumn{2}{|c|}{ Pyrrocidine A } & \multicolumn{2}{|c|}{ Pyrrocidine B } \\
\hline & MIC & $\mathrm{GI}_{50}$ & MIC & $\mathrm{GI}_{50}$ \\
\hline \multicolumn{5}{|l|}{ Bacillus mojavensis } \\
\hline NRRL B-14818 & $\leq 2$ & $>1-50$ & $\leq 10$ & $>5-50$ \\
\hline NRRL B-14700 & $\leq 1$ & $>1-50$ & $\leq 5$ & $>3-50$ \\
\hline \multicolumn{5}{|c|}{ Clavibacter michiganense subsp. nebraskense } \\
\hline NRRL B-41133 & $\leq 1$ & $>0.25-50$ & $\leq 10$ & $>1-50$ \\
\hline NRRL B-41134 & $\leq 2$ & $>0.25-50$ & $\leq 10$ & $>1-50$ \\
\hline \multicolumn{5}{|l|}{ Enterobacter agglomerans } \\
\hline NRRL B-14004 & $>50$ & $>50$ & $>50$ & $>50$ \\
\hline \multicolumn{5}{|c|}{ Pantoea stewartii subsp. stewartii } \\
\hline NRRL B-794 & $>50$ & $>50$ & $>50$ & $>50$ \\
\hline \multicolumn{5}{|l|}{ Pseudomonas fluorescens } \\
\hline NRRL B-4290 & $\leq 1$ & $>1-50$ & $\leq 10$ & $>1-50$ \\
\hline NRRL B-14678 & $\leq 1$ & $>1-50$ & $\leq 10$ & $>1-50$ \\
\hline
\end{tabular}


fungal strains (Table 1). Pyrrocidine A displayed significant activity against both fungal strains. However, in tests using an inoculum consisting of both hyphal cells and conidia, pyrrocidine A was less active against $F$. verticillioides (Table 2). An example of differential inhibition of spore germination and vegetative growth by antifungal antibiotics was reported for $F$. oxysporum f. sp. radicis-cucumerinum (49).

The present results suggest that seed-infecting endophytes and pathogens of maize that display similar disease symptoms or share relevant ecological characteristics (54) can also exhibit a similar pattern of sensitivity to pyrrocidine A. As a group, stalk and ear rot pathogens of maize that are also causal organisms of seedling blights $(22,52)$ (e.g., S. maydis, F. graminearum, R. zeae, and $N$. oryzae) were most sensitive to pyrrocidine A (Table 2). $T$. viride causes a severe ear rot of maize but was less sensitive to pyrrocidine A. Trichoderma spp. in general are resistant to antibiotics produced by other microorganisms (16). Although Trichoderma spp. are recognized for their mycoparasitic behavior and production of antifungal antibiotics, strains representing a few taxa have been reported to cause diseases of apple, maize, or alfalfa (4). As a colonist of maize, T. viride appears to bridge the ecological divide between symptomless endophyte in healthy maize stalks (45), virulent ear-rotting pathogen (52), and presumptive mycoparasite (50).

Numerous fungal taxa are recognized as colonists of the phylloplane and pathogens causing lesions on maize leaves, with symptoms characterized as leaf spots, leaf streaks, and leaf blights (52). In the present study, each of the three fungal taxa representing this ecological group displayed significant in vitro sensitivity to pyrrocidine A (Table 2). Among these fungi, Cochliobolus lunata produces a damaging leaf spot disease in hot, humid maize-growing areas (27). Alternaria alternata and Cladosporium cladosporioides are common saprophytes and symptomless colonists of the phylloplane of healthy plants, invading the leaves and forming spores as a response to early leaf senescence. Alternaria spp. are also reported to cause a leaf blight in the central corn belt while $C$. cladosporioides may produce symptoms of seed rot, although neither disease has been reported to be of economic significance (52).

Among the kernel-rotting saprotrophs, Aspergillus flavus and $E$. ochrosalmoneum were more sensitive to pyrrocidine A than A. niger or Penicillium oxalicum (Table 2). In addition to being known for infesting maize seed and contaminating them with aflatoxins (54), A. flavus is also recognized as an entomopathogen (44). E. ochrosalmoneum produces citreoviridin in maize grown in the southeastern United States (55) and shows a specificity for sporulating on the conidial heads of A. flavus although it has yet to be determined if the fungus is a mycoparasite (19). To our knowledge, there are no reports demonstrating microbial interference with maize seed infection by $A$. niger (47) or P. oxalicum (20).

F. proliferatum $F$. subglutinans, $F$. verticillioides, and $F$. oxysporum are symptomless seedborne endophytes of healthy maize plants and displayed little or no sensitivity to pyrrocidines (Table 2). These fungi are associated with various human infections and shown to be generally resistant to most clinical antifungal agents (25). F. proliferatum $(26,33)$ and $F$. subglutinans $(21,24)$, have not been the focus of research on seed transmission and systemic whole-plant infection as with $F$. verticillioides $(30,32,60) . F$. oxysporum is not known to cause any characteristic disease symptoms of maize $(23,24)$ yet was the most frequent isolate from rotted mesocotyls 40 to 80 days after planting (36). Interestingly, F. oxysporum NRRL 37597 represents the seed borne mycohost of Arthrobotrys sp. NRRL 37598, the parasitized mycohost having been isolated from a surface-disinfected white corn seed that was plated with grain sampled at Cerro Gordo, IL. This group of endophytes is associated with Fusarium seed rot of maize, especially kernels damaged from insect herbivory $(29,31,40)$, as well as stalk rot in mature maize plants $(9,52)$. However, none are regarded as aggressive pathogens when compared with fungi recognized as the primary cause of stalk rot, $S$. maydis and $F$. graminearum (52). Seed infected with $F$. verticillioides were less likely to also be infected with other fungal pathogens of maize $(7,37,53,57)$, suggesting that $F$. verticillioides may have a "protective effect" by suppressing the growth of more destructive pathogens $F$. graminearum and $S$. maydis (37). F. verticillioides is recognized as producing disease symptoms when responding to exclude primary pathogens from maize tissues severely damaged by insect herbivory $(31,39,40)$ or in response to other forms of environmental stress that lead to premature plant senescence $(9$, 29,45). It could be expected that Acremonium zeae and Fusarium endophytes present in healthy stem tissues are also recorded among bacteria and fungi, constituting the "disease complex" in necrotic stem tissues associated with stalk rot $(9,45)$.

Mycoparasites capable of attacking other fungi and used as biocontrol agents showed little or no sensitivity to pyrrocidines (Table 2). Fisher et al. (12) recorded V. lecanii as a seedborne endophyte of maize, isolating the fungus from healthy stem core tissues. The fungus is known as both a mycoparasite and a pathogen of insects $(1,13,15,28)$, producing vertilecanins which displayed antiinsectan activity against the corn earworm Helicoverpa zeae, along with 2-decenedioic acid, reported as a nematicidal product from the nematode-trapping fungus Pleurotus ostreatus (43). Penicillium spp. in the subgenus Biverticillium have been observed to parasitize other seed-infecting fungi (54) and may be recorded as seed-rotting pathogens when sporulating heavily on seed initially rotted by Fusarium spp. or another suitable mycohost. Among 15 species of Penicillium isolated from maize, Penicillium funiculosum and P. oxalicum were the only species that could invade and colonize maize ears (8).

In all tests, with bacteria or fungi, pyrrocidine A was more active than B, as was earlier shown in tests with Candida albicans and gram-positive bacteria, including drug-resistant strains (18). Natural infection of germinated maize seed with pyrrocidineproducing genotypes of $A$. zeae may protect maize seedlings from Clavibacter michiganense subsp. nebraskense, which can be transmitted in maize seed (5) and produces a systemic vascular wilt of maize plants (51). A. zeae might also interfere with the ability of $B$. mojavensis to suppress $F$. verticillioides infection of maize seedlings $(2,3)$ or with the natural establishment of Pseudomonas fluorescens in healthy maize plants, thereby reducing the efficacy of biocontrol strains $(12,14,48)$.

The present results have shown that pyrrocidine A exhibited potent activity against $S$. maydis, $F$. graminearum, and $C$. michiganense subsp. nebraskaense, each of which are seedborne pathogens that can cause severe seedling blights and vascular wilts of maize. Maize seedlings grown from pathogen-infected seed or attacked by soilborne pathogens may not survive to produce mature plants bearing seeds (42). During this period of seedling vulnerability, pyrrocidine antibiotics, as acquired chemical defenses, could contribute to endophyte defense as $A$. zeae spreads within imbibed and germinated seed and establishes itself within the mesocotyl and root crown of emerging seedlings (45). How might this work? A hypothesis is offered in which abiotic or biotic forms of damage to plant tissues trigger a xylem-blocking response in those vascular bundles which are most vulnerable to pathogen ingress. Mucilage, gels, or gum-like substances secreted into xylem vessels provide a preferred substrate for $A$. zeae growth and pyrrocidine production. Microscopic observations revealed, that whenever $A$. zeae was found to be present in xylem vessels, it was growing "vigorously" on these gum-like substances and associated pentose sugars (17). In this example, pyrrocidines would be concentrated within individual vascular bundles, providing an efficient means of delivering a robust and targeted antimicrobial chemical defense. This hypothesis assumes that plants are grown from healthy seed infected with $A$. zeae. The 
fungus is most commonly found in the pedicel and abscission layer of seed but may also infect the germ and endosperm, particularly when seed were first soaked for $40 \mathrm{~h}$ before dissection (45). Growing from germinated seed, A. zeae invades seedling roots, the mesocotyl, and the root crown, also forming single celled propagules which move within the xylem sap of healthy maize tissues and are capable of increasing their numbers through microcyclic conidiation (D. T. Wicklow, unpublished data). This results in A. zeae being 'prepositioned' in the root crown as well as the lower nodes and internodes of healthy stem tissues, where the fungus can effectively respond to abiotic or biotic forms of damage to maize tissues that enable pathogen establishment. The root crown represents a critical conduit for pathogen access to the vascular bundles of the stem and an opportunity to rapidly spread throughout the plant. Maize responds to mechanical wounding, even in the absence of microbes, by initiating a xylem-blocking response in which mucilage and phenolics are secreted into xylem vessels (10). These authors considered the gels and gums that formed in xylem vessels of maize stems that were wound inoculated with A. zeae (46) as being "protective" and a part of the plant defense response. Furthermore, the release of gels and gumlike substances into vascular bundles has also been associated with hereditary factors and physiological stress influenced by environmental conditions such as drought or imbalanced fertility (17). The potential role of host-sensitive cerebroside elicitors produced by $A$. zeae (58) in activating this maize plant defense response also needs to be explored.

In the present study, we have shown that endophytes and pathogens of maize can differ substantially in their in vitro sensitivities to pyrrocidine antibiotics. The organisms found to be most sensitive to these antibiotics are well-established pathogens of maize. Pyrrocidine-producing A. zeae endophytes may reduce the diversity and abundance of maize pathogen assemblages, as has been shown for Neotyphodium endophytes of grasses (38). At the same time, pyrrocidines were largely ineffective against protective endophytes, including mycoparasites, which produce symptomless infections and have been shown to interfere with more virulent maize pathogens. Insensitivity to pyrrocidines could facilitate the coexistence of A. zeae with other protective endophytes and mycoparasites, thereby extending the diversity and range of acquired endophyte defenses.

\section{ACKNOWLEDGMENTS}

We thank K. D. Rogers, S. K. Drenkhahn, and J. Brown for their valued technical assistance. Mention of trade names or commercial products in this publication is solely for the purpose of providing specific information and does not imply recommendation or endorsement by the United States Department of Agriculture.

\section{LITERATURE CITED}

1. Askary, H., Benhamou, N., and Brodeur, L. 1997. Ultrastructural and cytochemical investigations of the antagonistic effect of Verticillium lecanii on cucumber powdery mildew. Phytopathology 87:359-368.

2. Bacon, C. W., and Hinton, D. M. 2002. Endophytic and biological control potential of Bacillus mojavensis and related species. Biol. Control 23:274-284.

3. Bacon, C. W., Yates, I. E., Hinton, D. M., and Meredith, F. 2001. Biological control of Fusarium moniliforme in maize. Environ. Health Perspect. 109:325-332.

4. Bailey, B. A., and Lumsden, R. D. 1998. Direct effects of Trichoderma and Gliocladium on plant growth and resistance to pathogens. Pages 185204 in: Trichoderma and Gliocladium, Vol. 2. Enzymes, Biological Control and Commercial Applications. C. P. Kubicek and G. E. Harman, eds. Taylor and Francis, London.

5. Biddle, J. A., McGee, D. C., and Braun, E. J. 1990. Seed transmission of Clavibacter michiganensis ssp. nebraskensis in corn. Plant Dis. 74:908911.

6. Bigelis, R., He, H., Yang, H. Y., Chang, L. P., and Greenstein, M. 2006. Production of fungal antibiotics using polymeric solid supports in solid- state and liquid fermentation. J. Ind. Microbiol. Biotechnol. 33:815-826.

7. Blaney, B. J., Ramsey, M. D., and Tyler, A. L. 1986. Mycotoxins and toxigenic fungi in insect-damaged maize harvested during 1983 in Far North Queensland. Aust. J. Agric. Res. 37:235-244.

8. Caldwell, R. W., Tuite, J. F., and Carlton, W. W. 1981. Pathogenicity of penicillia to corn ears. Phytopathology 71:175-180.

9. Christensen, J. J., and Wilcoxsen, R. D. 1966. Stalk Rot of Corn. (Phytopathological Monograph No. 3.) American Phytopathology Society, St. Paul, MN.

10. Crews, L. J., McCully, M. E., and Canny, M. J. 2003. Mucilage production by wounded xylem tissue of mature maize roots: time course and stimulus. Funct. Plant Biol. 30:755-766.

11. Deyrup, S. T 2006. Chemical investigations of endophytic and fungicolous fungi. Ph.D. thesis, University of Iowa, Iowa City.

12. Fisher, P. J., Petrini, O., and Lappin Scott, H. M. 1992. The distribution of some fungal and bacterial endophytes in maize (Zea mays L.). New Phytol. 122:299-305.

13. Gams, W. 1971. Cephalosporium-artige Schimmelpilze (Hymenomycetes). G. Fischer, Stuttgart, Germany.

14. Haas, D., and Keel, C. 2003. Regulation of antibiotic production in rootcolonizing Pseudomonas spp. and relevance for biological control of plant disease. Annu. Rev. Phytopathol. 41:117-153.

15. Hall, R. A. 1981. The fungus Verticillium lecanii as a microbial insecticide against aphids and scales. Pages 483-498 in: Microbial Control of Pest and Plant Diseases 1970-1980. H. D. Burges, ed. Academic Press, London.

16. Harman, G. E., Latorre, B., Agosin, E., San Martin, R., Riegel, D. G., Nielsen, P. A., Tronsmo, A., and Pearson, R. C. 1996. Biological and integrated control of Botrytis bunch rot of grape using Trichoderma spp. Biol. Control. 7:259-266.

17. Harris, M. R. 1936. The relationship of Cephalosporium acremonium to the black-bundle disease of corn. Phytopathology 26:985-980.

18. He, H., Yang, H. Y., Bigelis, R., Solum, E. H., Greenstein, M., and Carter, G. T. 2002. Pyrrocidines A and B, new antibiotics produced by a filamentous fungus. Tetrahedron Lett. 43:1633-1636.

19. Horn, B. W. 2005. Colonization of wounded peanut seeds by soil fungi: selectivity for species from Aspergillus section Flavi. Mycologia 97:202217.

20. Johann, H., Holbert, J. R., and Dickson, J. G. 1931. Further studies on Penicillium injury to corn. J. Agric. Res. 43:757-790.

21. Kabeere, F., Hill, M .J., and Hampton, J. G. 1997. The transmission of Fusarium subglutinans from maize seeds to seedlings. Australas. Plant Pathol. 26:126-130.

22. Koehler, B. 1957. Pericarp injuries in seed corn: prevalence in dent corn and relation to seedling blights. Ill. Agric. Exp. Stn. Bull. 617:1-72.

23. Kommedahl, T., Windels, C. E., and Stucker, R. E. 1979. Occurrence of Fusarium species in roots and stalks of symptomless corn plants during the growing season. Phytopathology 69:961-966.

24. Leslie, J. F., Pearson, C. A. S., Nelson, P. E., and Toussoun, T. A. 1990. Fusarium species from corn, sorghum, and soybean fields in the central and eastern United States. Phytopathology 80:343-350.

25. Leslie, J. F., and Summerell, B. A. 2006. The Fusarium Laboratory Manual. Blackwell Publishing, Ames, IA.

26. Logrieco, A., Moretti, A., Ritieni, A., Bottalico, A., and Macchia, L. 1995. Occurrence and toxigenicity of Fusarium proliferatum from preharvest maize ear rot, and associated mycotoxins, in Italy. Plant Dis. 79:727-731.

27. McGee, D. C. 1994. Maize Diseases, a Reference Source for Seed Technologists. American Phytopathological Society. St. Paul, MN.

28. Mendgen, K. 1981. Growth of Verticillium lecanii in pustules of stripe rust (Puccinia striformis) Phytopathol. Z. 102:301-309.

29. Miller, J. D. 2001. Factors that affect the occurrence of fumonisin. Environ. Health Perspect. 109(Suppl. 2):321-324.

30. Munkvold, G. P., and Carlton, W. M. 1997. Influence of inoculation method on systemic Fusarium moniliforme infection of maize plants grown from infected seeds. Plant Dis. 81:211-216.

31. Munkvold, G. P., Hellmich, R. L., and Showers, W. B. 1997. Reduced Fusarium ear rot and symptomless infection in kernels of maize genetically engineered for European corn borer resistance. Phytopathology 87:1071-1077.

32. Munkvold, G. P., McGee, D. C., and Carlton, W. M. 1997. Importance of different pathways for maize kernel infection by Fusarium moniliforme. Phytopathology 87:209-217.

33. Olah, B., Jeney, A., and Hornok, L. 2006. Transient endophytic colonization of maize tissues by Fusarium proliferatum. Acta Phytopathol. Entomol. Hung. 41:185-191.

34. Pan, J. J., Baumgarten, A. M., and May, G. 2008. Effects of host plant environment and Ustilago maydis infection on the fungal endophyte community of maize (Zea mays). New Phytol. 178:147-156.

35. Poling, S. M., Wicklow, D. T., Rogers, K. D., and Gloer, J. B. 2008. Acremonium zeae, a protective endophyte of maize, produces dihydro- 
resorcylide and 7-hydroxydihydroresorcylides. J. Agric. Food Chem. 56:3006-3009.

36. Ramsey, M. D. 1990. Etiology of root and stalk rots of maize in north Queensland. Disease development and associated fungi. Australas. Plant Pathol. 19:2-12.

37. Rheeder, J. P., Marasas, W. F. O., and van Wyk, P. S. 1990. Fungal associations in corn kernels and effects on germination. Phytopathology 80:131-134.

38. Rudgers J. A., and Clay K. 2005. Fungal endophytes in terrestrial communities and ecosystems. Pages 423-442 in: The Fungal Community: Its Organization and Role in the Ecosystem, Third ed. J. Dighton, J. F. White, and P. Oudemans, eds. Taylor \& Francis, New York.

39. Schaafsma, A. W., Miller, J. D., Savard, M. E., and Ewing, R. J. 1993. Ear rot development and mycotoxin production in corn in relation to inoculation method, corn hybrid, and species of Fusarium. Can. J. Plant Pathol. 15:185-192.

40. Schulthess, F., Cardwell, K. F., and Gounou, S. 2002. The effect of endophytic Fusarium verticillioides on infestation of two maize varieties by lepidopterous stemborers and coleopteran grain feeders. Phytopathology 92:120-128.

41. Seghers, D., Wittebolle, L., Top, E. M., Verstraete, W., and Siciliano, S. D. 2004. Impact of agricultural practices on the Zea mays L. endophyte community. Appl. Environ. Microbiol. 70:1475-1482.

42. Smith, D. R., and White, D. C. 1988. Diseases of corn. Pages 687-766 in: Corn and Corn Improvement, 3rd ed. G. F. Sprague and J. W. Wild, eds. American Society of Agronomy, Crop Science Society of America, Madison, WI.

43. Soman, A. G., Gloer, J. B., Angawi, R. F., Wicklow, D. T., and Dowd, P. F. 2001. Vertilecanins: new phenopicolinic acid analogues from Verticillium lecanii. J. Nat. Prod. 64:189-192.

44. St. Leger, R. J., Screen, S. E., and Shams-Pirzadeh, B. 2000. Lack of host specialization in Aspergillus flavus. Appl. Environ. Microbiol. 66:320324.

45. Sumner, D. K. 1968. Ecology of corn stalk rot in Nebraska. Phytopathology 58:755-760.

46. Tagne, A., Neergaard, E., Hansen, H. J., and The, C. 2002. Studies of host pathogen interactions between maize and Acremonium strictum from Cameroon. European J. Plant Pathol. 11: 95-100.

47. Taubenhaus, J. J. 1920. A study of the black and yellow molds of ear corn. Tex. Agric. Exp. Stn. Bull. No. 270.

48. Troxler, J., Zala, M., Natsch, A., Moenne-Loccoz, Y., and Defago, G. 1997. Autecology of the biocontrol strain Pseudomonas fluorescens
CHA0 in the rhizosphere and inside roots at later stages of plant development. FEMS Microbiol. Ecol. 23:119-130.

49. Tzatzarakis, M. N., Tsatsakis, A. M., Charvalos, E., and Vakalonakis, D. 2001. Comparison of in vitro activities of amphotericin, clotrimazole, econazole, miconazole, and nystatin against Fusarium oxysporum. J. Environ. Sci. Health B 36:331-340.

50. Vakili, N. G. 1985. Mycoparasitic fungi associated with potential stalk rot pathogens of corn. Phytopathology 75:1201-1207.

51. Vidaver, A. K., Gross, D. C., Wysong, D. S., and Doupnik, B. L. 1981. Diversity of Corynebacterium nebraskense strains causing Goss's bacterial wilt and blight of corn. Plant Dis. Rep. 65:480-483.

52. White, D. G. 1999. Compendium of Corn Diseases, Third ed. American Phytopathological Society Press, St. Paul, MN.

53. Wicklow, D. T. 1988. Patterns of fungal association within maize kernels harvested in North Carolina. Plant Dis. 72:113-115.

54. Wicklow, D. T. 1994. The mycology of stored grain. Pages 197-249 in: Stored Grain Ecosystems, D. S. Jayas, N. D. G. White, and W. E. Muir eds. Marcel Dekker, New York.

55. Wicklow, D. T., and Cole, R. J. 1984. Citreoviridin in standing corn infested by Eupenicillium ochrosalmoneum. Mycologia 76:959-961.

56. Wicklow, D. T., Hesseltine, C. W., Shotwell, O. L., and Adams, G. L. 1980. Interference competition and aflatoxin levels in corn. Phytopathology 70:761-764.

57. Wicklow, D. T., Horn, B. W., Shotwell, O. L., Hesseltine, C. W., and Caldwell, R. W. 1988. Fungal interference with Aspergillus flavus infection and aflatoxin contamination of maize grown in a controlled environment. Phytopathology 78:68-74.

58. Wicklow, D. T., Poling, S. M., and Summerbell, R. C. Occurrence of pyrrocidine and dihydroresorcylide production among Acremonium zeae populations from maize grown in different regions. Can. J. Plant Pathol. (In Press.)

59. Wicklow, D. T., Roth, S., Deyrup, S. T., and Gloer, J. B. 2005. A protective endophyte of maize: Acremonium zeae antibiotics inhibitory to Aspergillus flavus and Fusarium verticillioides. Mycol. Res. 109:610-618.

60. Wilke, A. L., Bronson, C. R., Tomas, A., and Munkvold, G. P. 2007. Seed transmission of Fusarium verticillioides in maize plants grown under three different temperature regimes. Plant Dis. 91:1109-1115.

61. Zinniel, D. K., Lambrecht, P., Harris, N. B., Feng, Z., Kuczmarski, D., Higley, P., Ishimaru, C. A., Arunakumari, A., Barletta, R. G., and Vidaver, A. K. 2002. Isolation and characterization of endophytic colonizing bacteria from agronomic crops and prairie plants. Appl. Environ. Microbiol. 68:2198-2207. 